\title{
Survey the Bacteriological Quality of Juice in the Juice Shop of Shahrood City and its Relationship with Food Safety Knowledge and Performance of Vendors in 2013-2014: A Case Study
}

\author{
Sakineh Mollaie Tavani $^{1^{*}}$, Emad Dehghanifard ${ }^{1}$, Ali Mehrali ${ }^{1,3}$, Gholam Ali Sharifi Arab $^{2}$, Alaleh Dehmanesh ${ }^{2}$ \\ 1. Ms.C student, Department of Environmental Health Engineering, School of Health, Alborz University of \\ Medical Sciences, Karaj, Iran \\ 2. Assistant Professor, Department of Environmental Health Engineering, School of Health, Alborz University of \\ Medical Sciences, Karaj, Iran \\ 3. Environmental Health Expert, Health Vice-chancellor of Shahrood University of \\ Medical Sciences, Shahrood, Iran \\ *E-mail: sakinehmolaei242@gmail.com
}

Received: 11 Jan 2017 ; Accepted: 14 May 2014

\begin{abstract}
Backgrounds and Objective: Juice drinks have high nutritional value, antioxidants, vitamins and minerals which are widely consumed due to therapeutic properties. The aim of this study was to survey the bacteriological quality of juices in Shahrood city.

Materials and Methods: This descriptive cross-sectional study was done in the spring and summer seasons of 2014-2015, on juices sold in the Shahrood city study. A self-report questionnaire confirmed by the ministry of health, with certain modifications (as needed), was applied to determine the bacteriological quality of juices and the relationship between food safety knowledge and practices of vendors. In this study, all juice shops ( 9 units) were considered and the research was carried out by visiting and completing the questionnaires. In order to determine the bacteriological quality of fruit juices, sampling was done from juice shops. The samples the assessed for the presence of Staphylococcus, E. coli, total coliform, yeast and mold counts by using standard methods. The results were compared with the standards of the Institute of Standards and Industrial Research of Iran. Then, obtained data were analyzed by Excel and SPSS software.

Result: About $16.12 \%$ of the samples contaminated to Staphylococcus aureus, $22.58 \%$ to Escherichia coli, $12.9 \%$ to total coliform, $38.7 \%$ to yeast and $9.67 \%$ to mold. Also, a significant correlation between parameters such as level of literacy (Education) of vendors, amount of sales, site and refrigerator hygiene, personal hygiene, food hygiene, and sanitation was existed $(\mathrm{P} \leq 0.001)$.

Conclusion: The results showed that all biological parameters were higher than the standard level, which was due to the lack of principles and rules of personal hygiene, food hygiene and sanitation. Hence, management, monitoring and purposeful education was much more needed for food safety supervision and training to prevent contamination of food with pathogenic agents, and greater emphasis on compliance with regulations is Article 13.
\end{abstract}

Keywords: Staphylococcus aureus, Escherichia coli, Total coliform count, Yeast and mold, juice, Shahrood city 


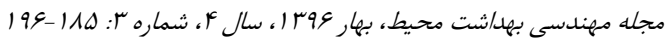

\title{
بررسى كيفيت باكتريولوزّيك آبميوه در آبميوه فروشى هاى \\ شهرستان شاهرود و ارتباط آن با دانش ايمنى مواد غذايى و عملكرد فروشند گان در سال عq-سوسا : مطالعه موردى
}

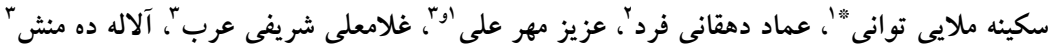

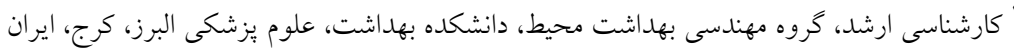

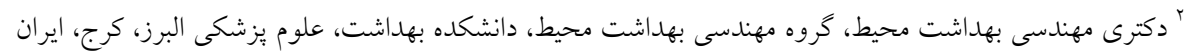

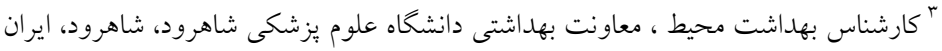

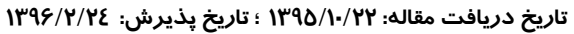

\section{حكيده}

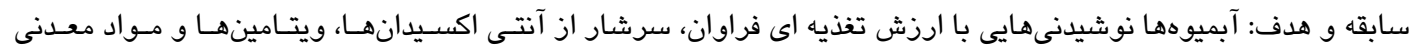

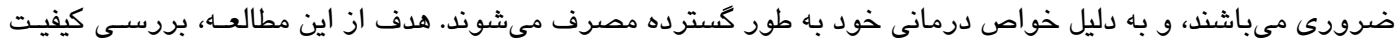

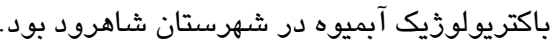

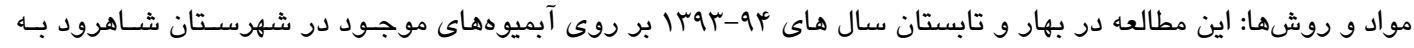

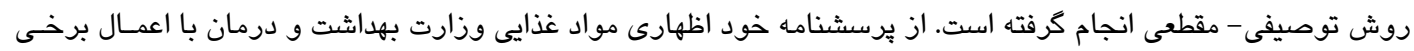

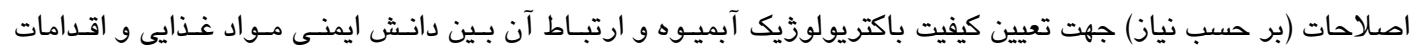

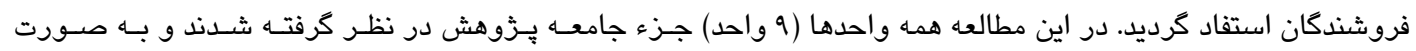

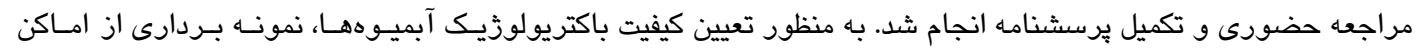

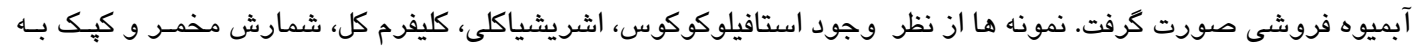

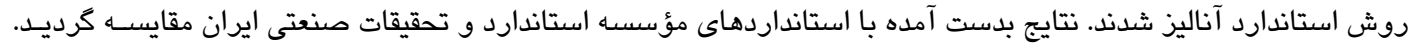

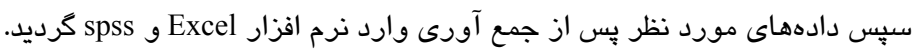

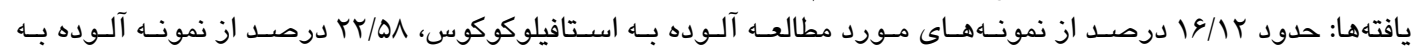

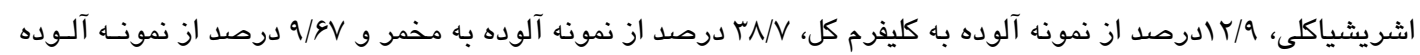

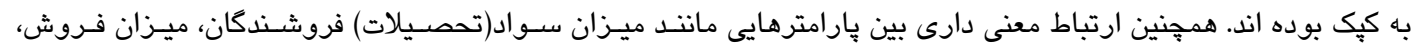

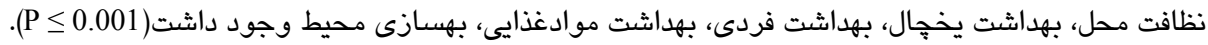

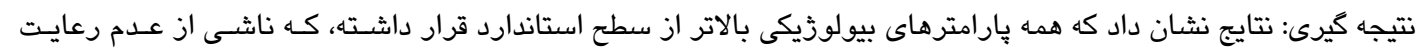

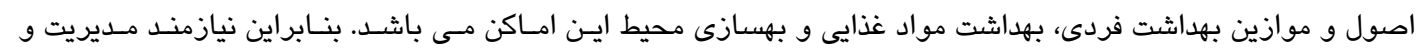

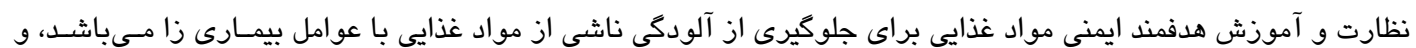

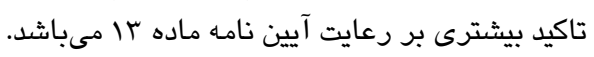

كلمات كليدى: استافيلوكوكوس اورئوس، اشيرشياكلى، كليفرم كل، شمارش مخمر و كيك، آبميوه، شاهرود 
است مخاطراتى را براى سلامت مصرف كنــــان بـهـ ارمغــان

مقدمه

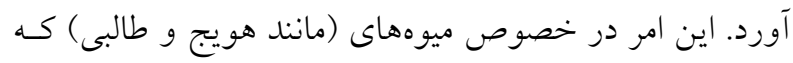

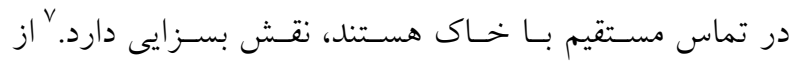

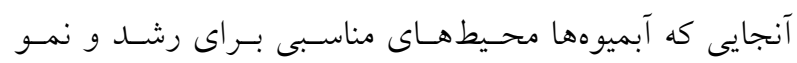

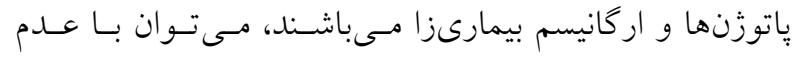
رعايت اصول و موازين بهداشتى و شرايط مناسـب در هنخـام

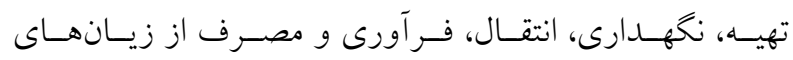
اقتصادى، فساد سريع مواد غـذايى و بيمـارىهـاى عفـونى در

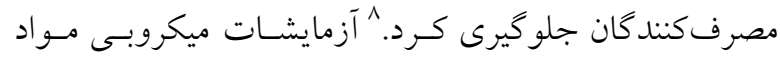

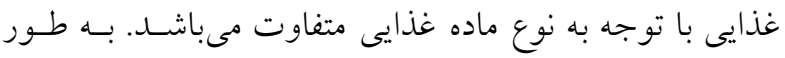

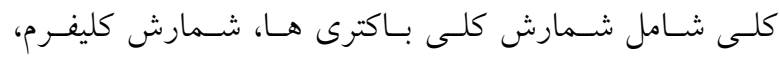
استافيلوكو كوس اورئوس، كيكى و مخمر و سالمونلا، اشريشـيا

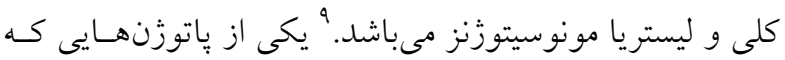

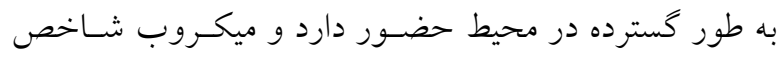

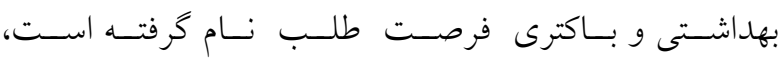

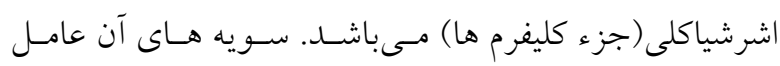

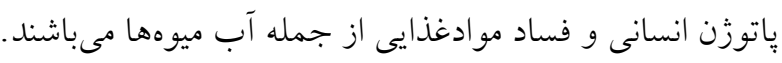

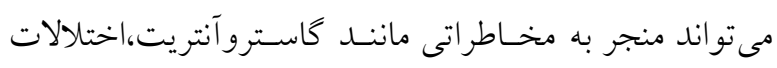

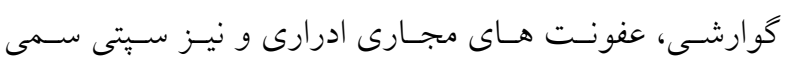
نوزادان، منتزيت وغيره گردد. از اين رو بر اساس استانداردهاى

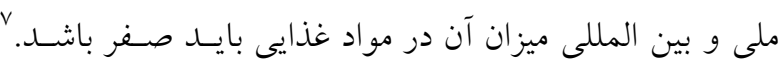
عدم حضور كليفـرم، اشيرشسياكلى، كيـى و مخمــر در محسيط

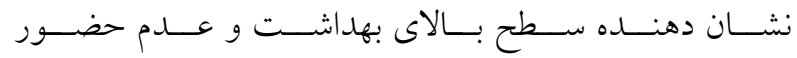

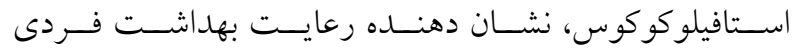

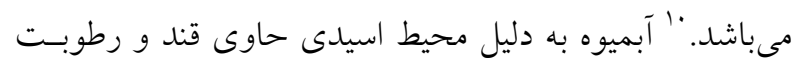

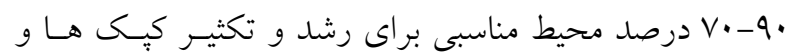

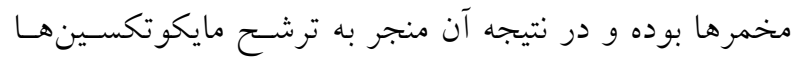
كرديده كه مىتواند مسموميتهايى را در انسانها و حيوانات ايجاد كند." لذا براى شاخص هاى بهداشتى در هـر جامعهداى

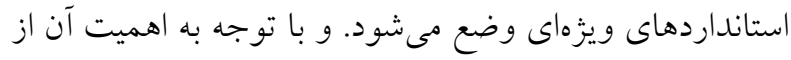

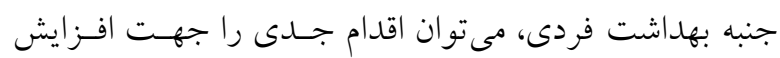

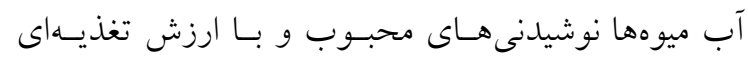

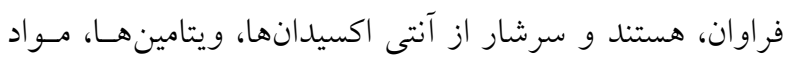

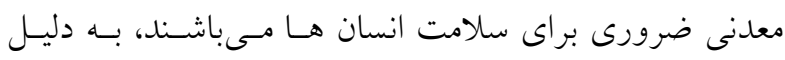

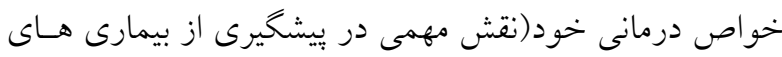
قلبى(نارسايى احتقانى قلب)، سرطان(سرطان يستان)، عفونت-

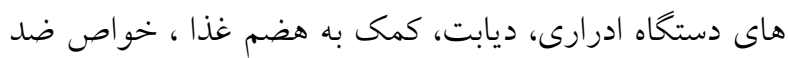

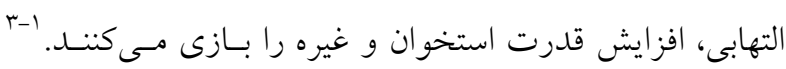

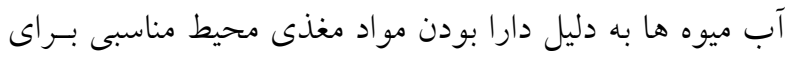
رشد باكترى هاى مقاوم به اسيد، كيك و مخمرها فراهم مسى -

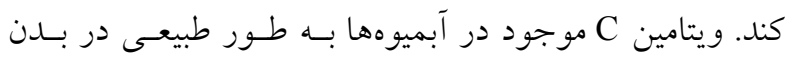

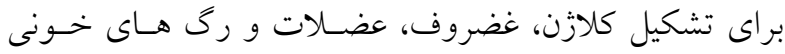
ضرورى بوده و هم:جنين در جذب آهـن كمـى مسى كنــ. بـه علاوه، يتاسيم بالا و سديم بايين ميوهها در حفظ فشـار خـون

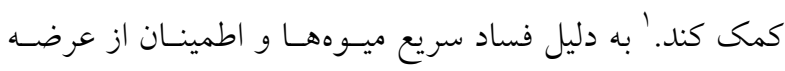

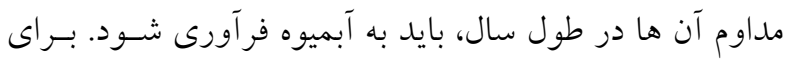

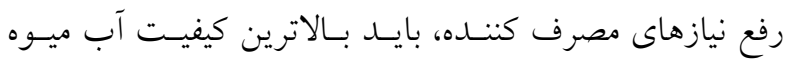

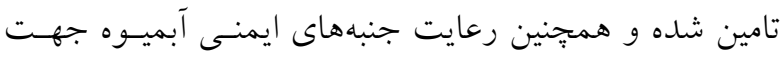
طولانى تر شدن عمر مفيد آن، از ملاحظات بسيارمهم مى بـاشد.

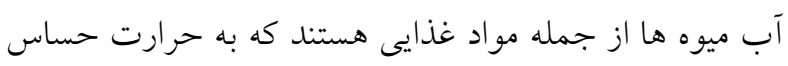

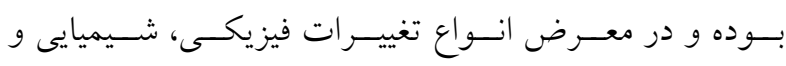

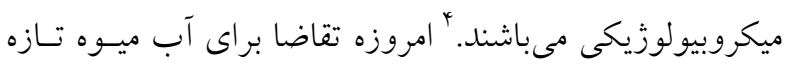

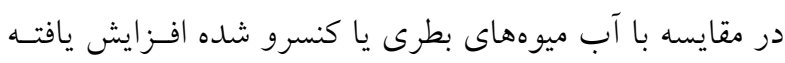

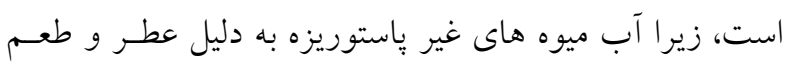

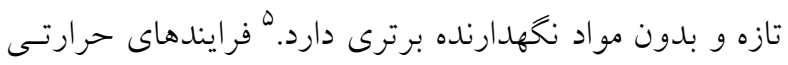

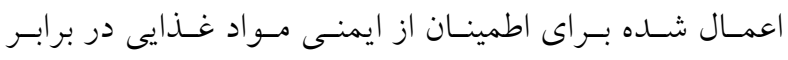

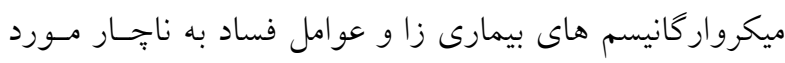

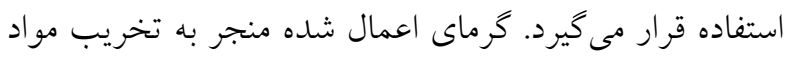
مغذى، بافت، رنغ، و عطـر و طعـم ميسوه هـا مسى شـود. ${ }^{9}$

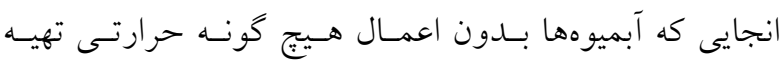

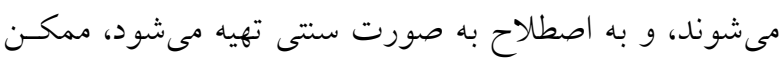


به بيمارى منتقله از غذا مى باشند. تعيين كيفيت ميكروبى مواد

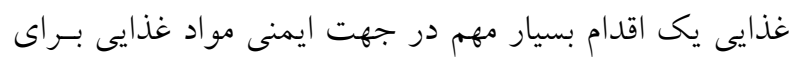

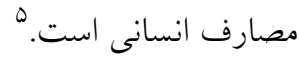

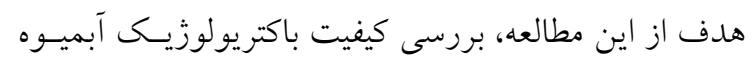
هاى عرضه شده در شهرستان شـاهرود و همجنـين ارزيـابى عملكرد فروشندكان از جنبه هـاى رعايست اصـول و مـوازين بهداشت فردى، بهداشت مواد غذايى و بهسـازى محسيط ايسن

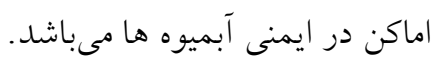

\section{مواد و روشها}

اين مطالعه در فصول بهار و تابستان سـال ؟و-شوץ| بـر روى آبميوههاى موجود در شهرستان شاهرود بـه روش توصسيفى -

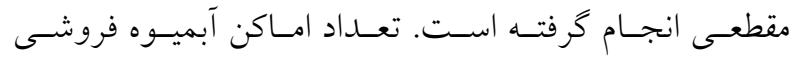

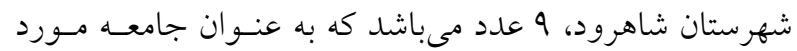
مطالعه انتخاب شدند. براى تعيين كيفيت باكتريولوزيك آبميـوه

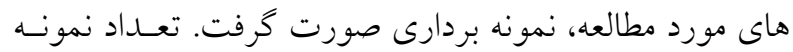

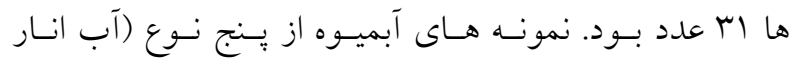

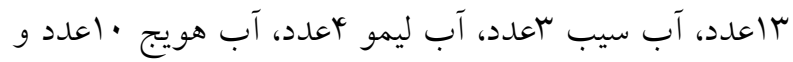

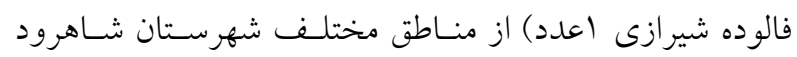

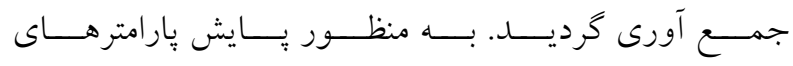

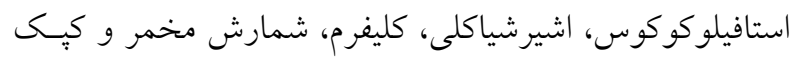

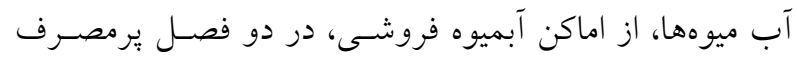

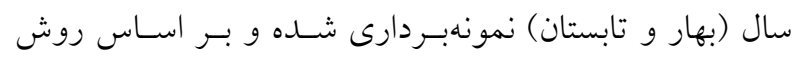

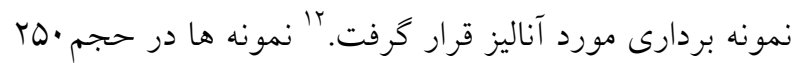

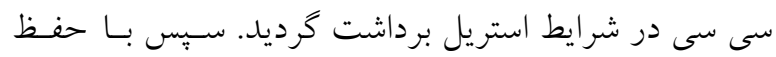

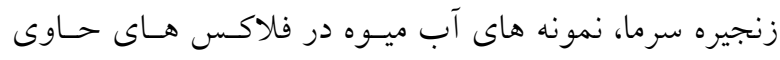

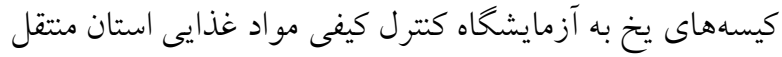

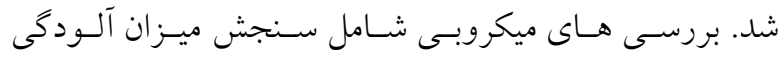

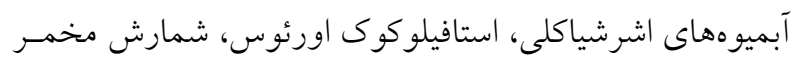

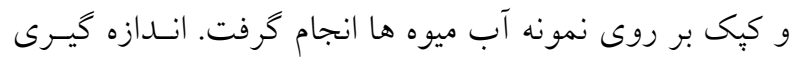

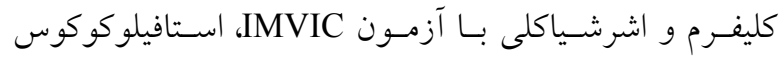

سطعح بهداشـى آبميـوههـاى توزيـع شــدهو رسـيدن بـهـ

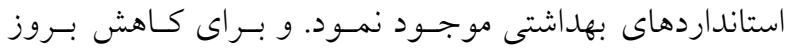

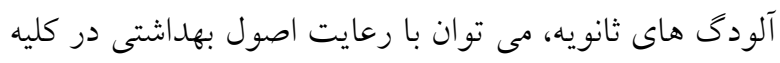

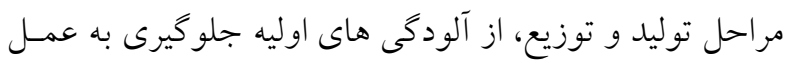

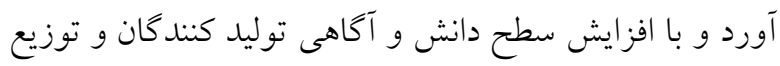

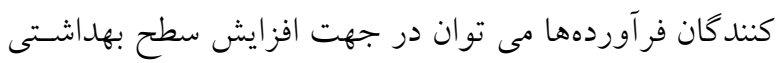

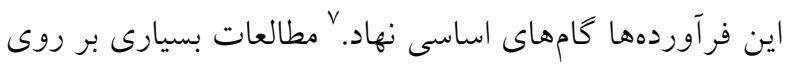

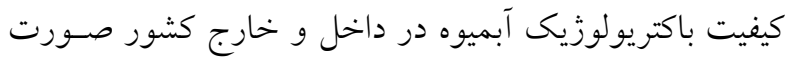
كرفته است. در مطالعهاى كه توسط عســرى و همكـارانش در زمينـه

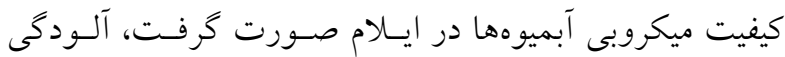

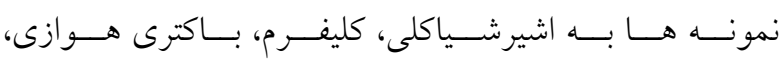
استافيلوكو كوس اورئوس و مخخمر نشان داده شــــ در مطالعـهـ

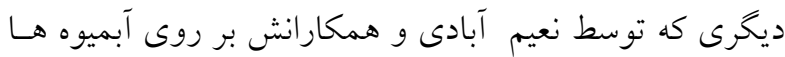

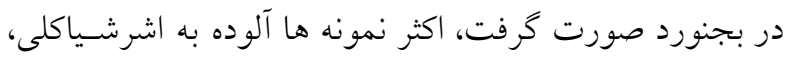

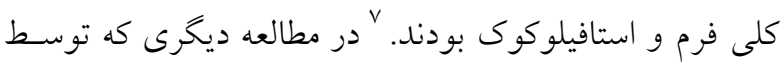

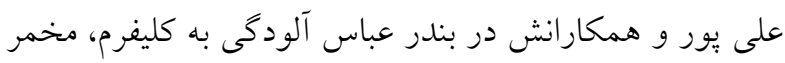

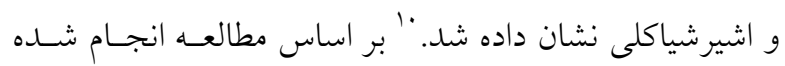
توسط Reddi و همكارانش، بروز بِاتوزن هاى منتقله از آبميوه

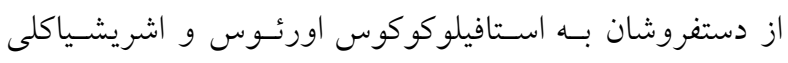

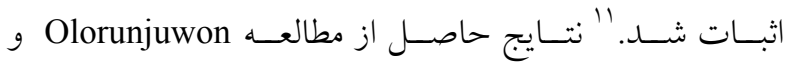
همكارانش نشان داد كه اسـتافيلوكوك، كليفـرم و مخمرهـا در

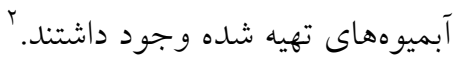

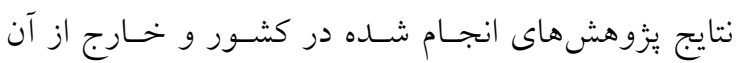

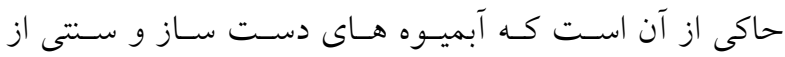

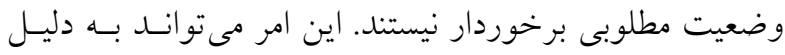

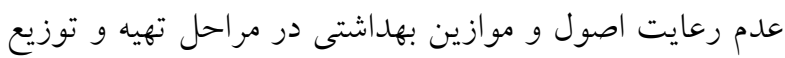
و فقدان آكاهى فروشندكان از مسائل موجود باشد و منجر بــــ بروز بيمارىهايى براى مصرف كنندكان شود.

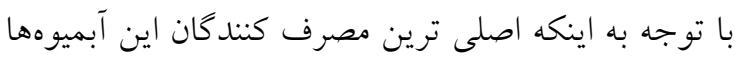

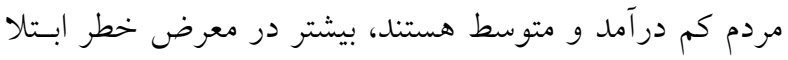


موادغذايى و بهـازى محيط انتخاب شـدند. در ايسن مطالعـه، تمامى واحدها (9 واحد) جزء جامعه يزوهش در نظـر گرفتسه شده و تكميل برسشنامه به صورت مراجعسه حضـورى انجـام شد. داده هاى مورد نظر، يس از جمــع آورى وارد نــــم افـزار Excel

\section{يافتهها}

بر اساس اندازه گيرىهاى انجام شده، از آبميوه هاى امـاكن آبميـو هفروشـى شهرسـتان شـاهرود جهــت بررسـى كيفيـت

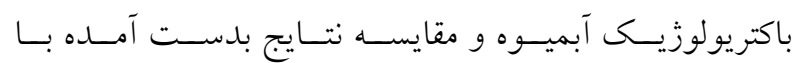
استانداردهاى مؤسسه استاندارد و تحقيقات صنعتى ايران كه در جدول ا آمده است نتايج به شرح ذيل مىباشد.
اورئوس با آزمون كواگولاز، شمارش كيك و مخمر از طريـق محيط كشت سابروز دكستروز آكار انجام شد. متوسـط تعـداد كلنى به عنوان واحد شمارش كلنى ثبت شده برحسب (CFU)

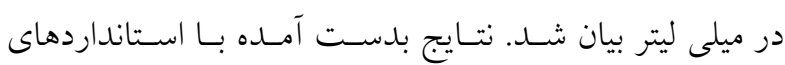
مؤسسه استاندارد و تحقيقات صنعتى ايران مقايسه كرديد. از يرسشنامه خود اظهارى مواد غذايى وزارت بهداشـت و درمان با اعمال برخى اصلاححات (بر حسب نياز) جهت تعيسين رابطه بين كيفيت باكتريولوزيك آبميـوه و دانسش ايمنسى مـواد

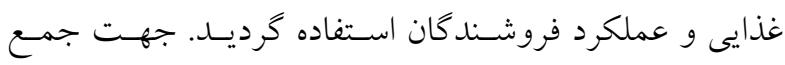
آورى اطلاعات كيفيت باكتريولوزيك آبميوه، متغيرهـاى سـن، جنس، ميزان سواد (تحصيلات) فروشـندكان، ميـزان فـروش،

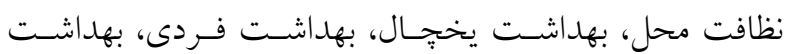

\begin{tabular}{|c|c|c|}
\hline حداكثر مجاز در يك ميلى ليتر & ويثخى & رديف \\
\hline منفى & باكترىهاى مقاوم به اسيد & 1 \\
\hline 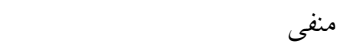 & باكترىهاى اسيد لاكتيك & r \\
\hline منفى & كيكى & r \\
\hline منفى & مخمر & r \\
\hline
\end{tabular}

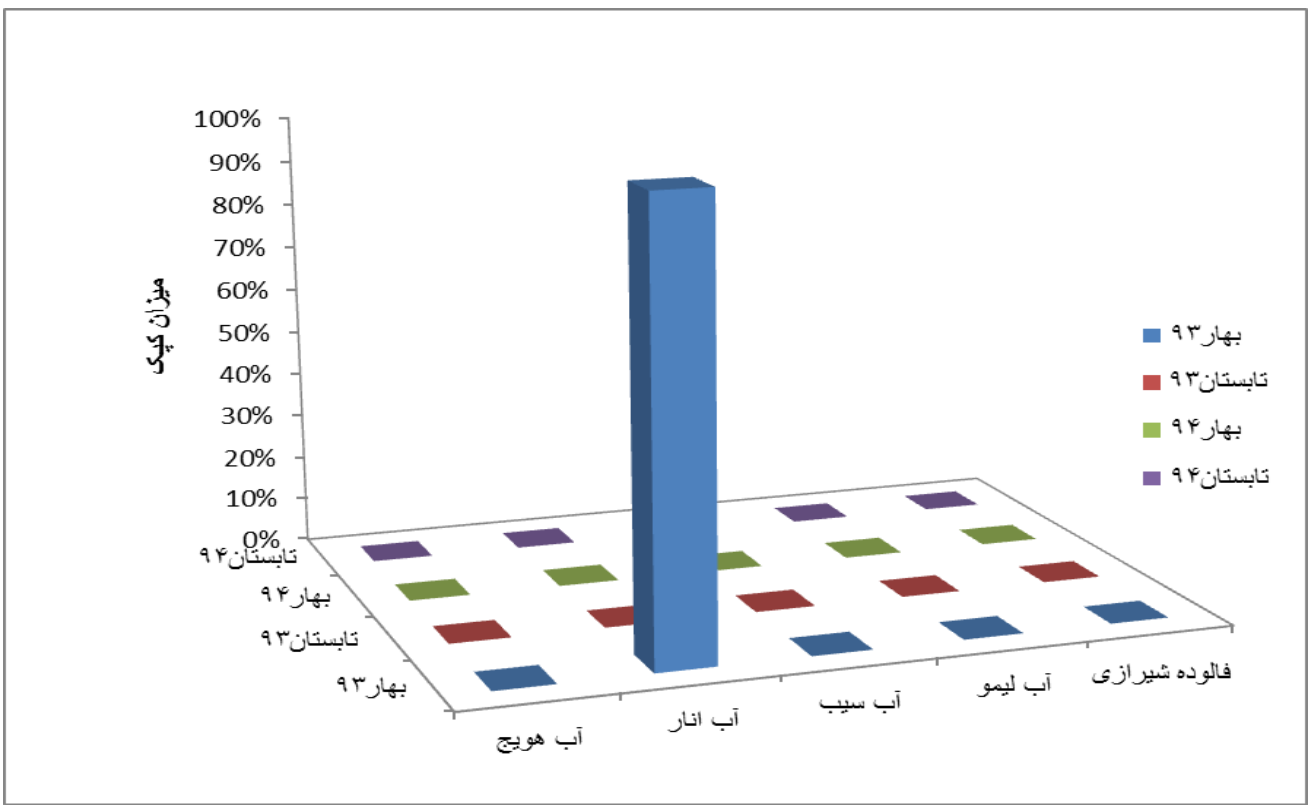

شكل ا: درصد نمونههاى آبميوه آلوده به كيك شهرستان شاهرود 
شـمارش مخمــر در آب هــويج در فصـول بهـار و تابسـتان

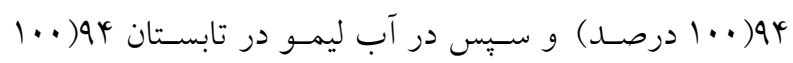

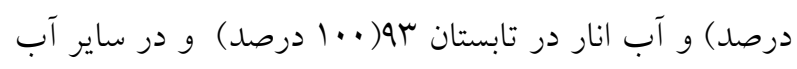
ميوهها موردى (صفر) مشاهده نشد.
با بررسى مقايسه نتايج شمارش كيك در دو فصل بهار و

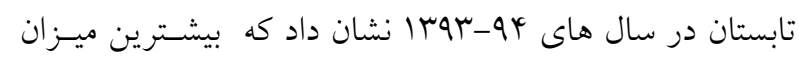

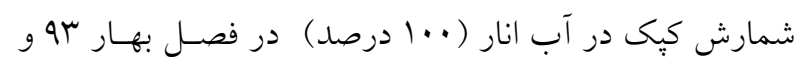
در ساير آبميوهها و فصول ديخر موردى (صفر) مشاهده نشد.

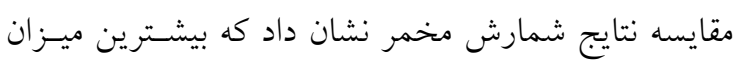

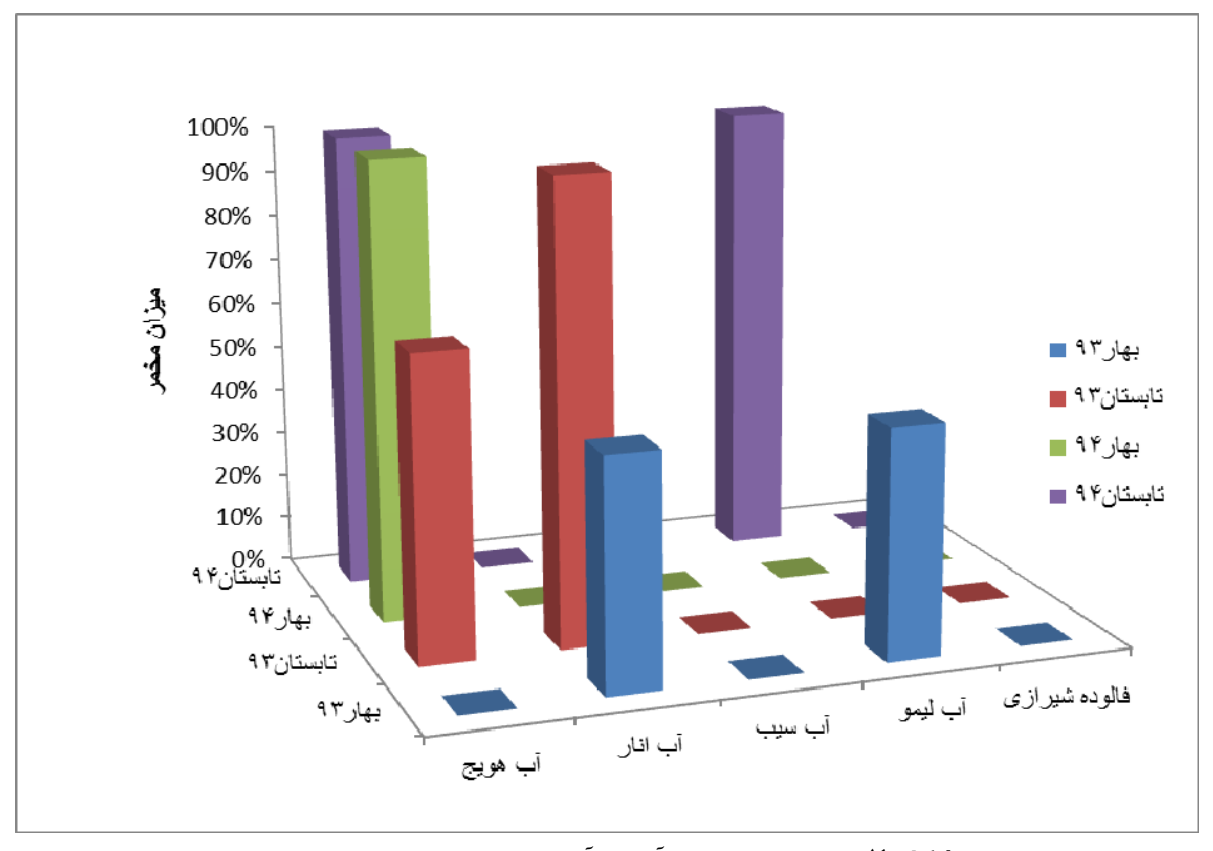

شكل r: درصد نمونههاى آبميوه آلوده به مخمر شهرستان شاهرود

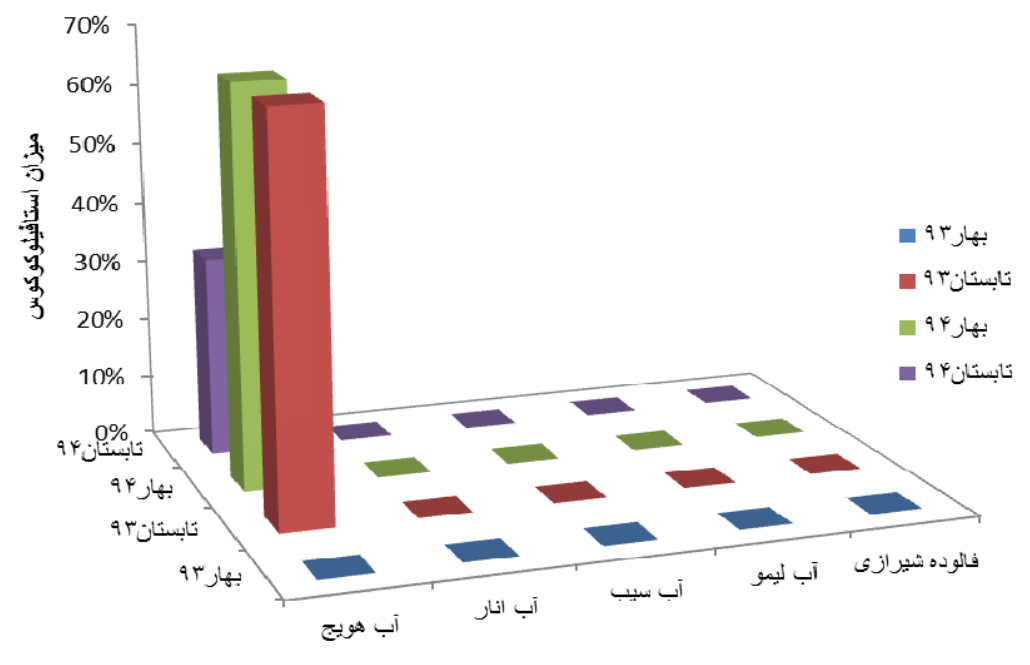

شكل سا: درصد نمونههاى آبميوه آلوده به استافيلوكوكوس شهرستان شاهرود 


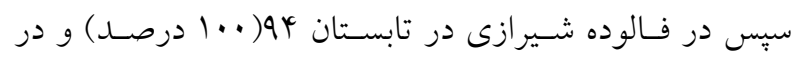
ساير آب ميوه ها موردى (صفر) مشاهده نشد. مقايسه نتايج بررسى كليفرم نشان داد كـه بيشـترين ميـزان شمارش كليفرم در آب هويج در فصل تابستان مو(49 درصد) و در ساير آب ميوه ها موردى (صفر) مشاهده نشد.
نتايج بررسى استافيلوكوكوس نشان داد كه بيشترين ميـزان شمارش مخمر در آب هـويج در فصـول تابسـتان سهو و بهـار 49494 درصد) و در ساير آب ميوه ها موردى (صفر) مشاهده

نتايج بررسى اشيرشـياكلى نشـان داد كـه بيشـترين ميـزان شمارش مخمر در آب هويج در فصل بهار 4و( +. آدرصد) و

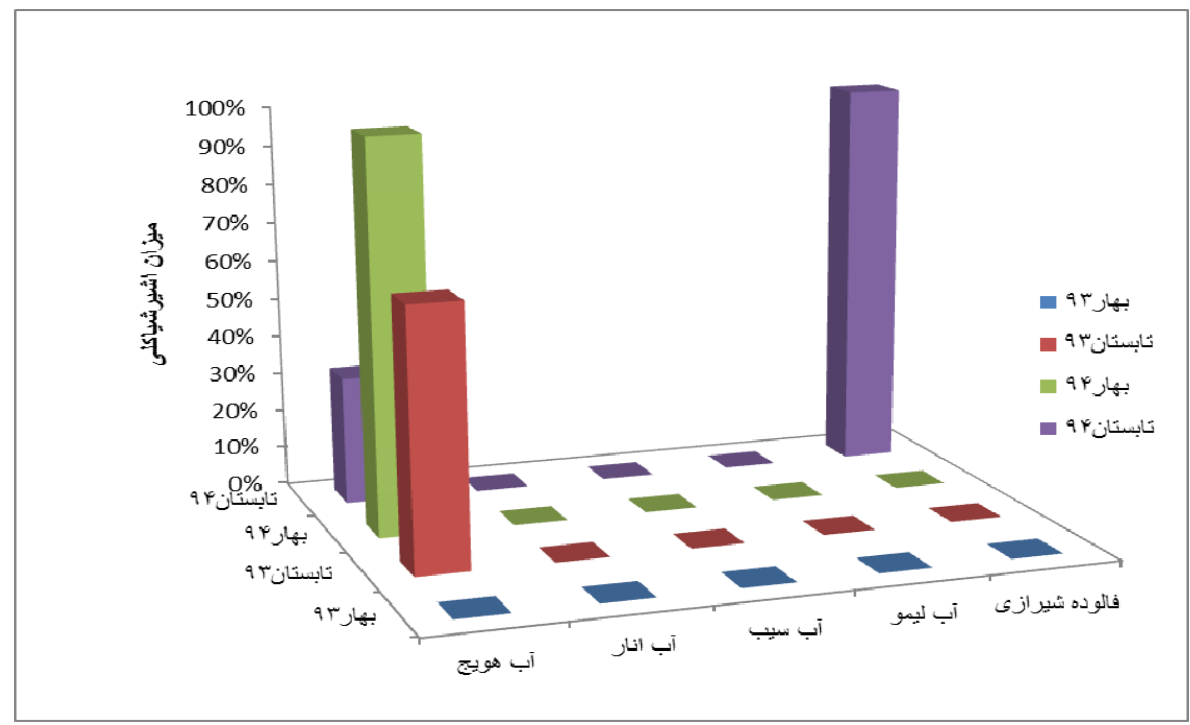

شكل ع: درصد نمونههاى آبميوه آلوده به اشيرشياكلى شهرستان شاهرود

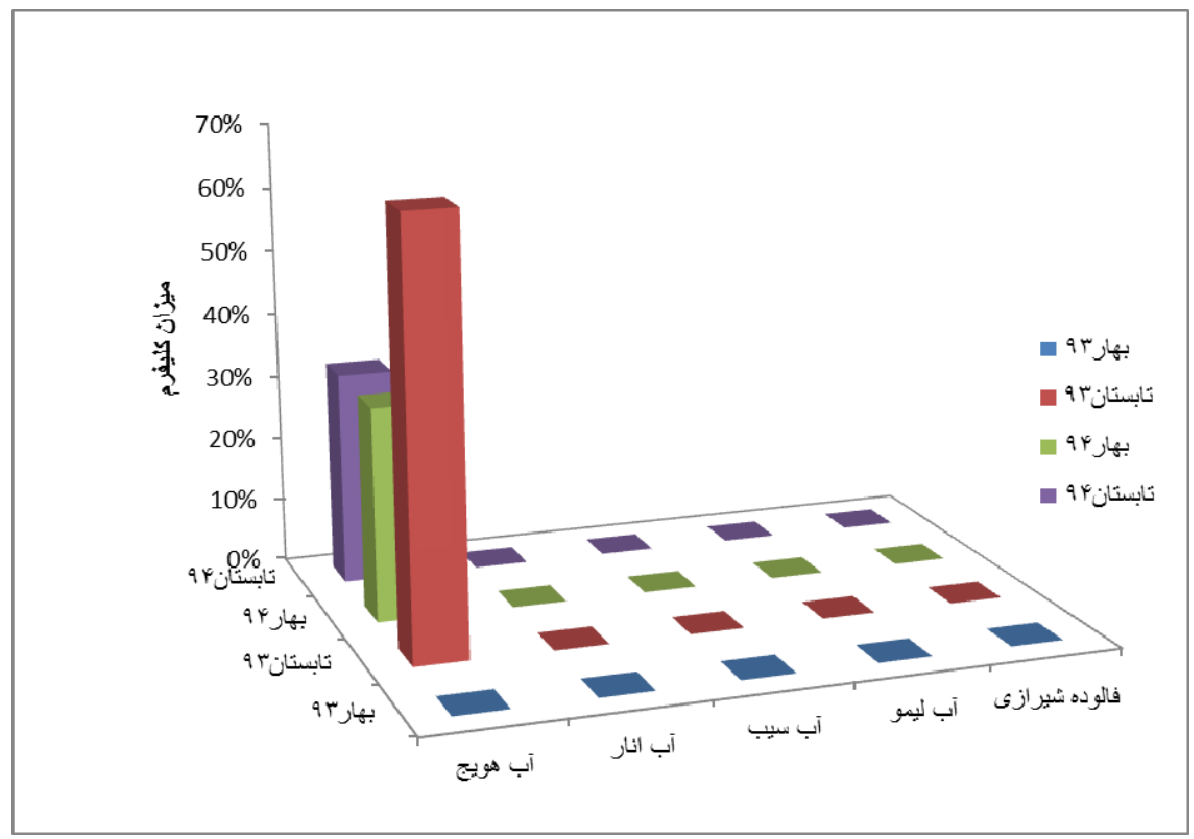

شكل ठ: درصد نمونههاى آبميوه آلوده به كليفرم شهرستان شاهرود 
سكينه ملايى توانى و همكاران

جدول r: ارتباط بين ويزگ هاى فردى فروشندكان با بهداشت محيط و ايمنى مواد غذايى

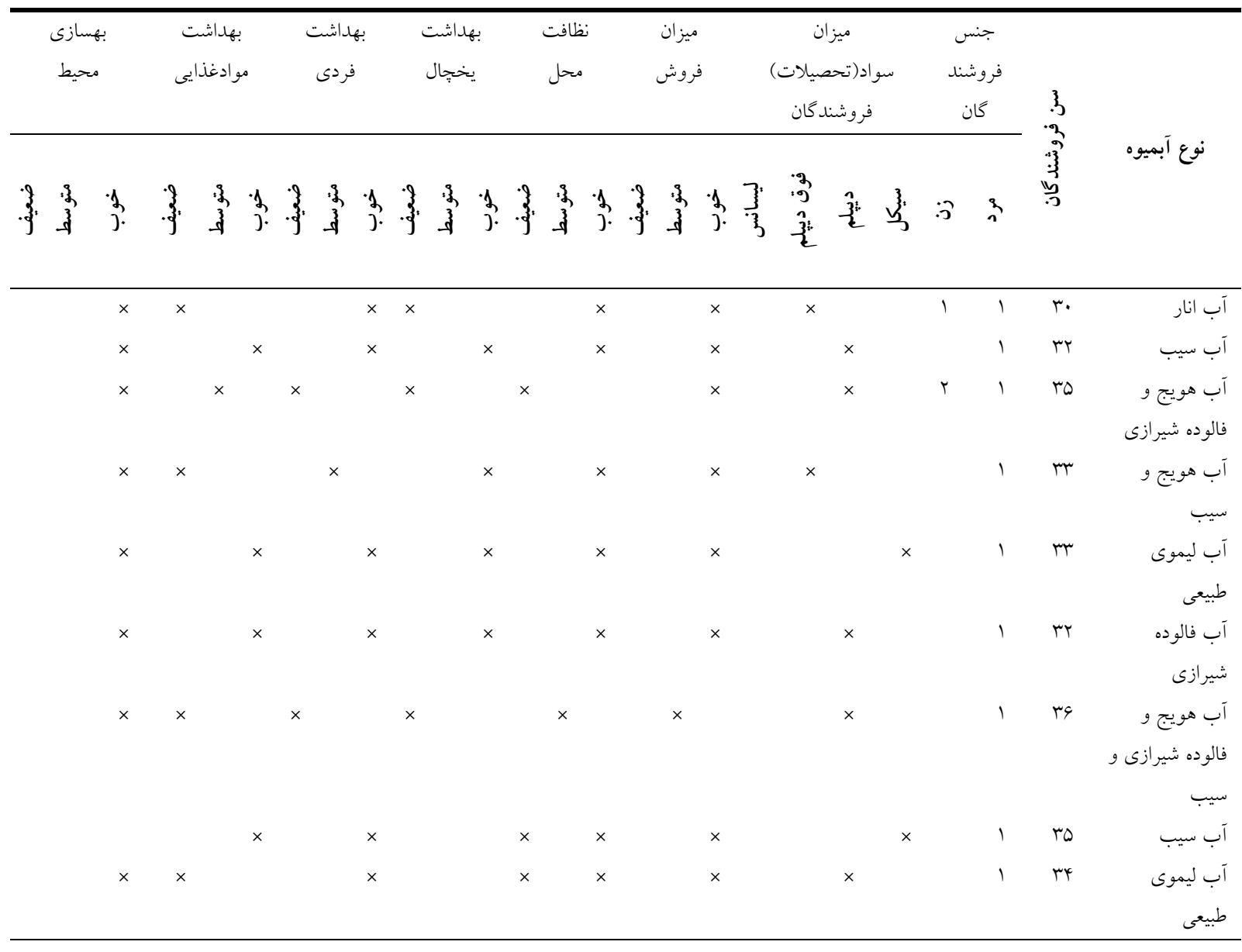

19/1 19/1 درصد بدست آمد. حضـور اسـتافيلوكوكوس اورئسوس

در آبميوهها ممكن است به دليل آلودگى با فلور طبيعى موجود در سطح يا در نقاط مختلف بدن انسان باشد. همجنين ممكـن

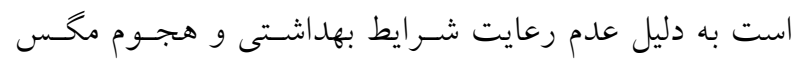
خانكى در واحد فروش باشد." بر اساس مطالعه انجـام شـده توسط Reddi و همكاران، بروز باتوزن هاى منتقله از آبميوه از

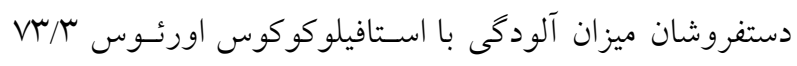
درصد بود." "در مطالعه عسـخرى و همكـاران، سم/سل درصــ نمونه هاى مورد بررسى بـه اسـتافيلوكوكوس اورئسوس آلـوده

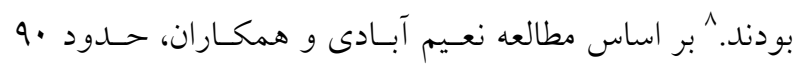

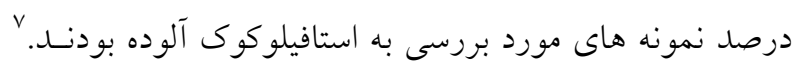
در مطالعه ديخرى كه توسط منخلى زاده و همكـاران، صـورت
بـهـ طـور معمـول آب ميـوههــا حـاوى يـك ميكروفلـور مىباشند كه در سـطح ميـوههـا در طـول برداشـت و يسس از برداشت، حمل و نقل، ذخيره سازى و يسردازش وجــود دارد.'

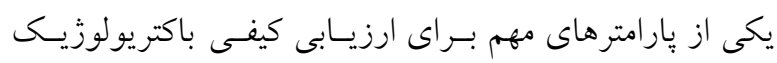

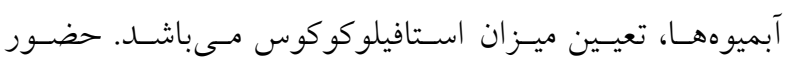
استافيلوكوكوس اورئوس يكى ديخر از شاخص عدم بهداشت فردى مى باشد. اين ارگانيسم به طور كسترده اى در طبيعت و

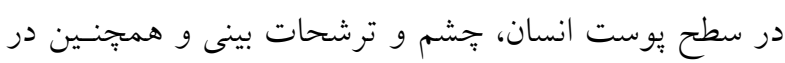

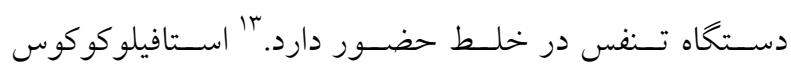
اورئوس، يك مزوفيل است و در شـيوع برخهى از مسـموميت

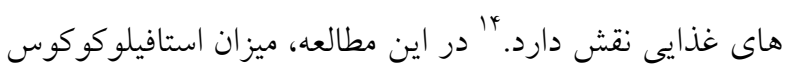


آلودخى مستقيم مــدفوعى يـا آلـودخى از محسيط را MPN/ml

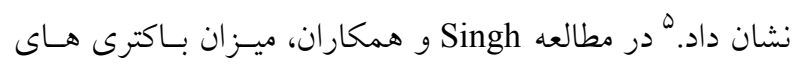

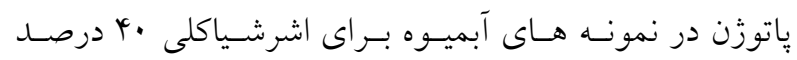

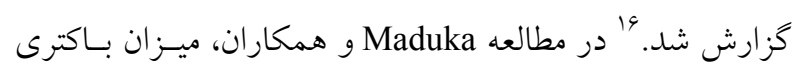

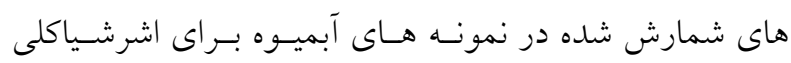

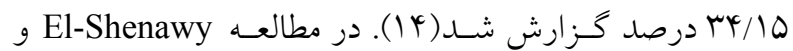

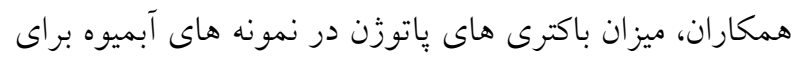

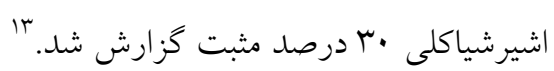

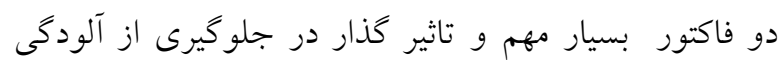

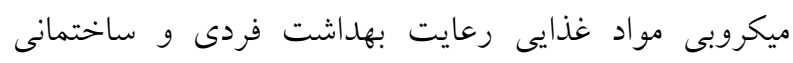

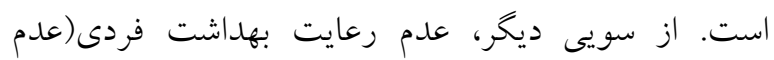

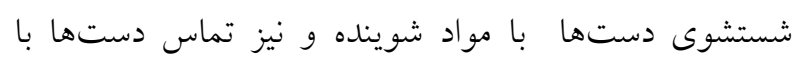

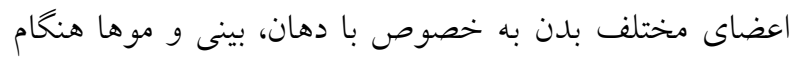

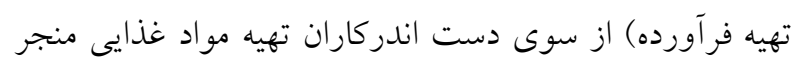

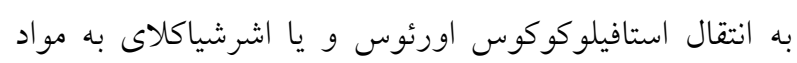

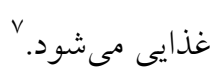

از بارامترهاى مهم ديخر براى ارزيابى كيفى باكتريولوزيك

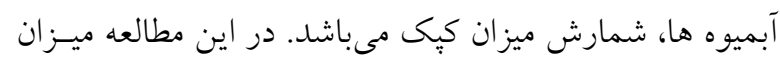

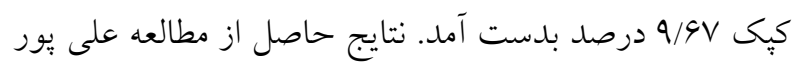

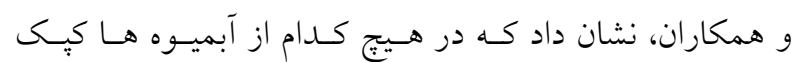

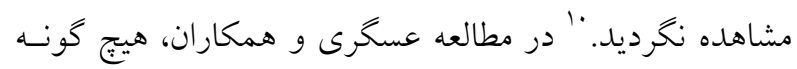

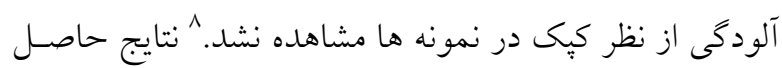

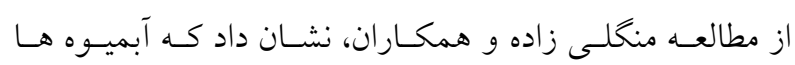

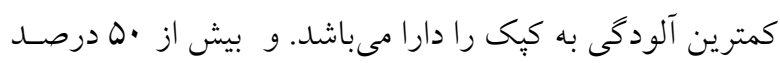
داراى آلودكى ميكروبى مى باشد. 10

از بارامترهاى مهم ديخر براى ارزيابى كيفى باكتريولوزيكى باتلى

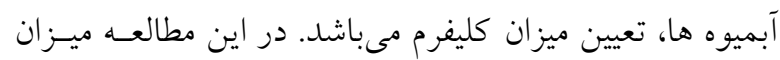

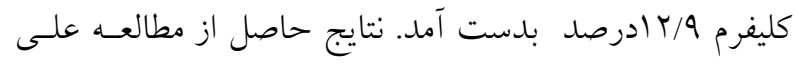

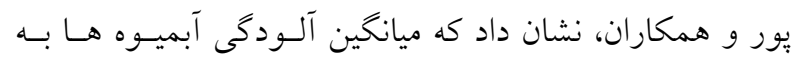

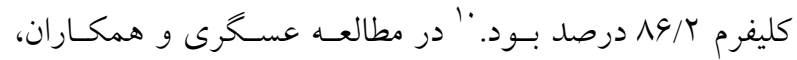

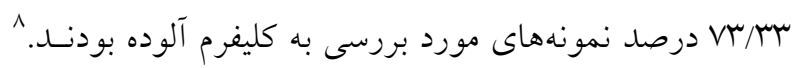

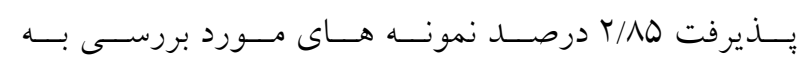

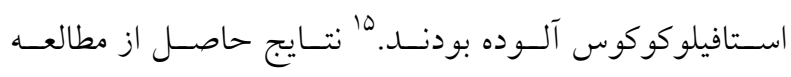

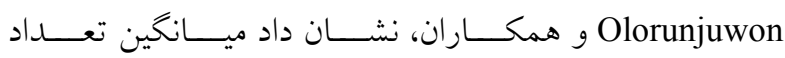
اسـتافيلوكوى Singh و

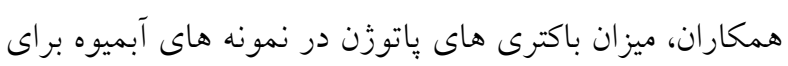

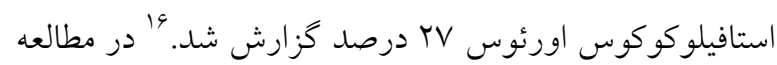
Maduka ومهكاران، ميـزان بـاكترىهـاى شـمارش شـــه در

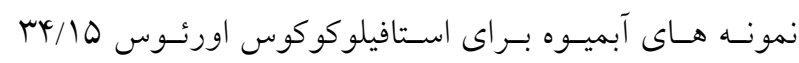

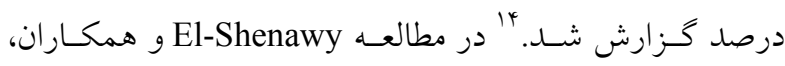

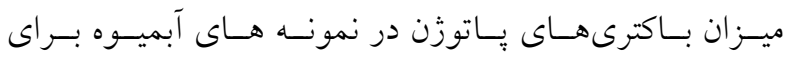

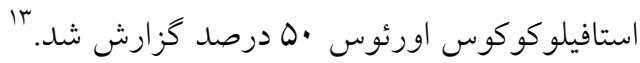

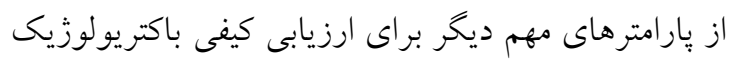

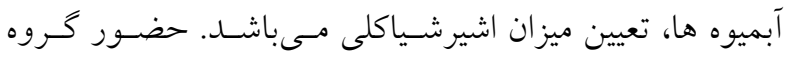

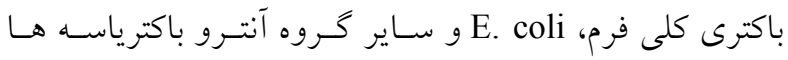

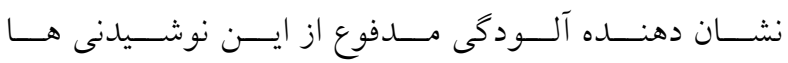

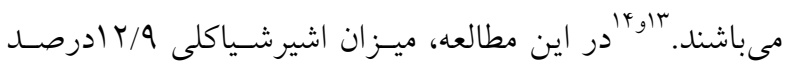
بدست آمد. نتايج حاصل از مطالعه على يور و همكاران، نشان

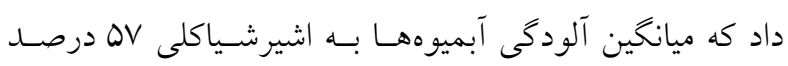

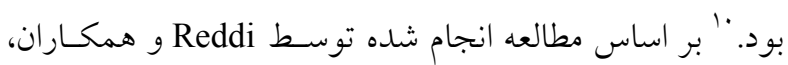

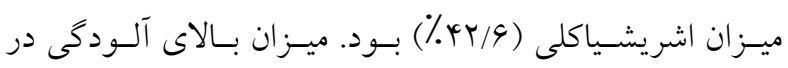

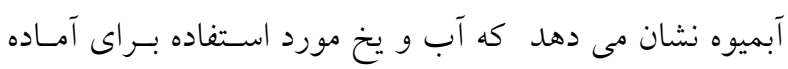

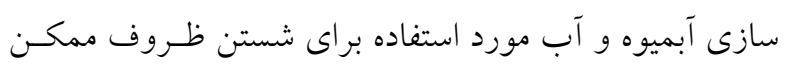

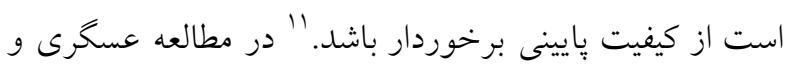

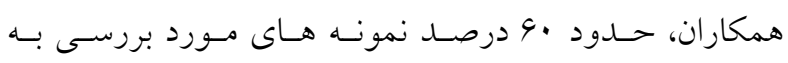

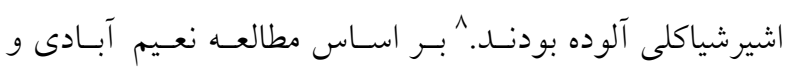

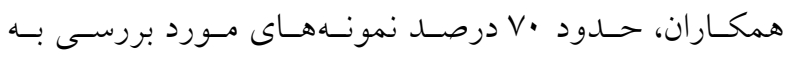

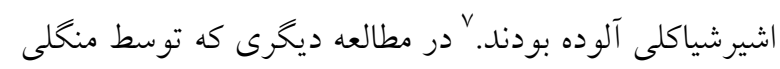

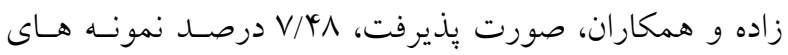

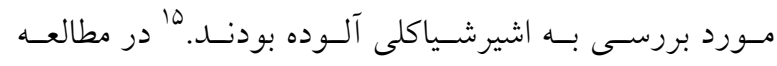

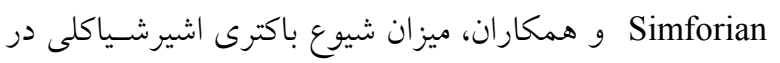

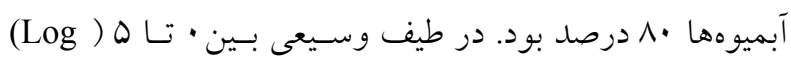




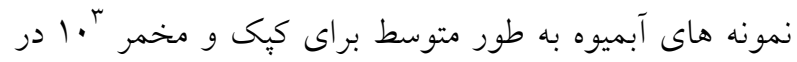

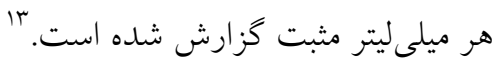

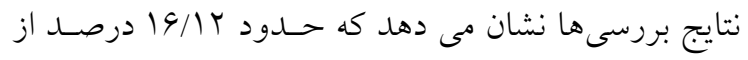

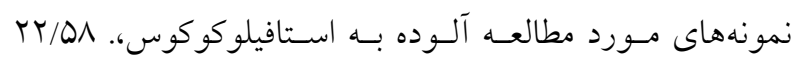

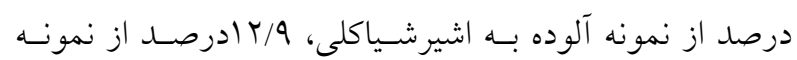

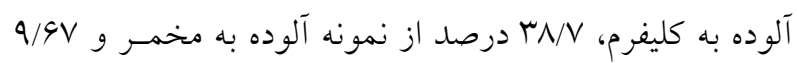

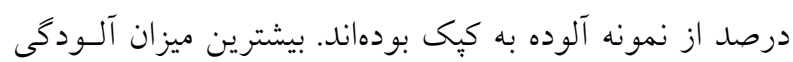

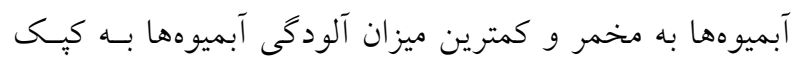

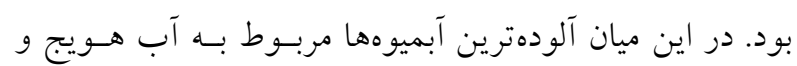

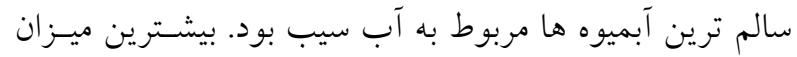

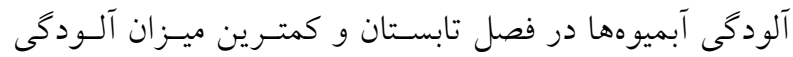
آبميوه ها در فصل بهار مشاهده شد. آميوهاد

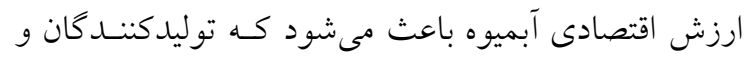

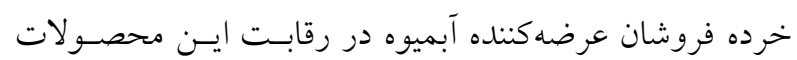

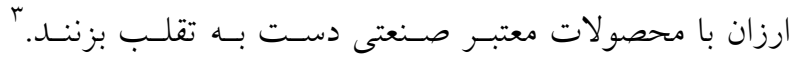

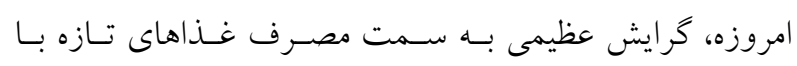

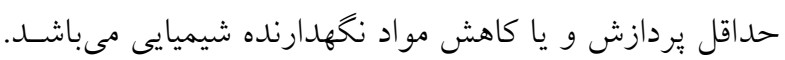
آب ميوه هايى كه به طور مستقيم از ميوه هــا(نـه از كنسـانتره)

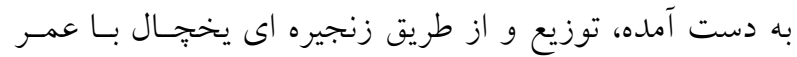

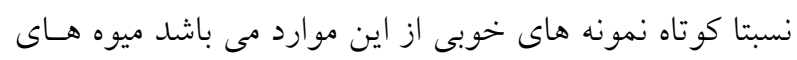
تازه برش خورد بلدون اعمال هر گونه عمليات حرارتى و مواد

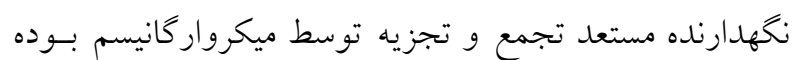

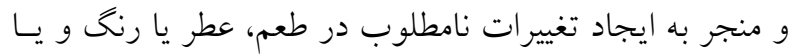

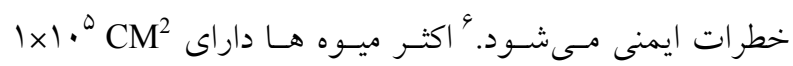
باكترى بر روى سطح خود مى باشند. اما بهداشت بايد دركليه

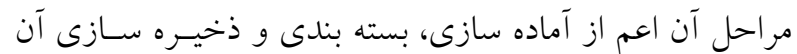
ها كه در معرض آلودخى ميكروبى هستند دخيل باشد عوامـل

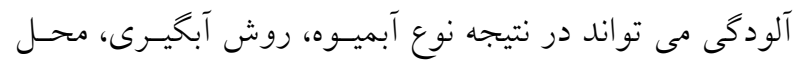

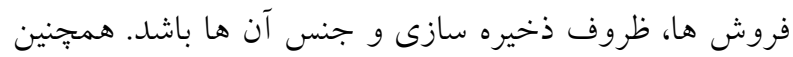

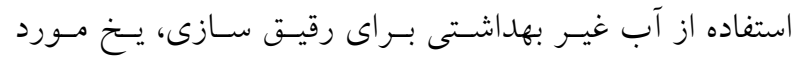

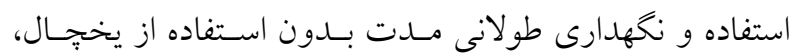

بر اساس مطالعه نعـيم آبـادى و همكـاران، حسدود \&9 درصـــ

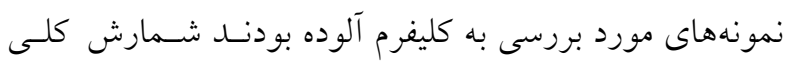

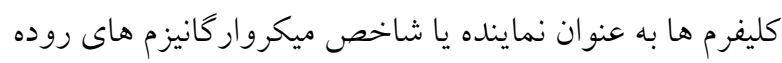

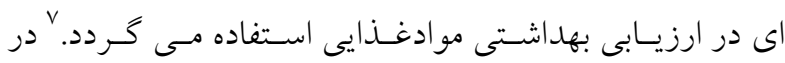

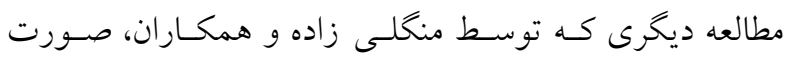

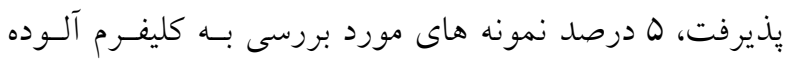

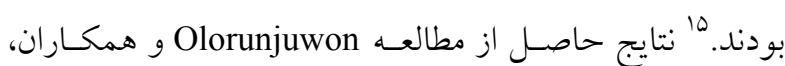

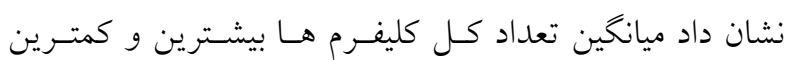
ميزان آن به ترتيب cfu/ml

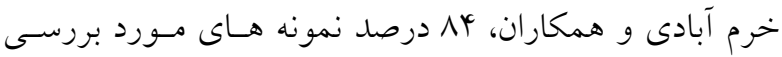

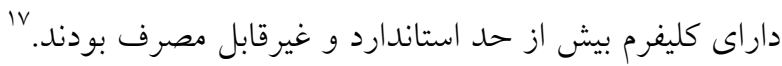

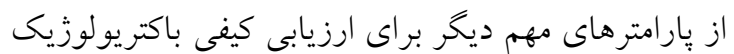
آبميوهها، شمارش ميزان مخمر مىباشد. در اين مطالعه، ميـزان

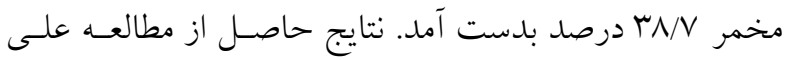

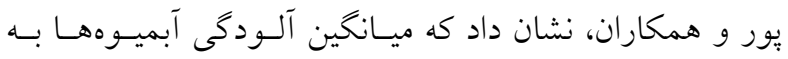

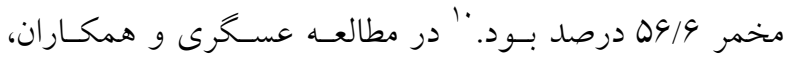

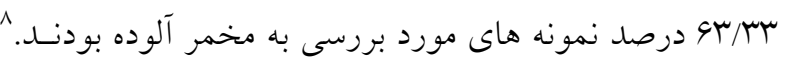

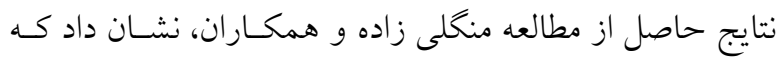

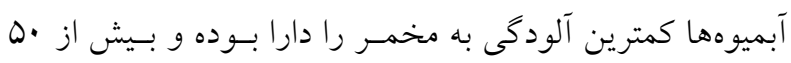

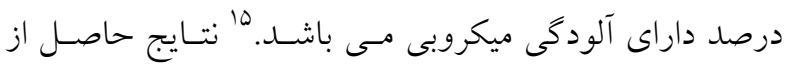

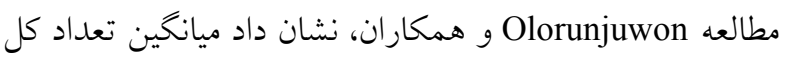

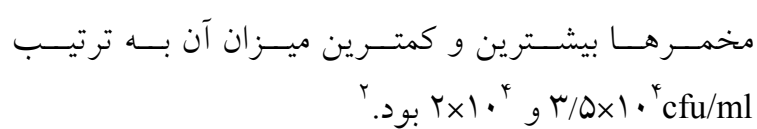
از جمله عواملى كه باعث افزايش بار آلودكى آبميوهها

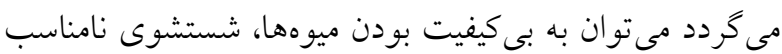

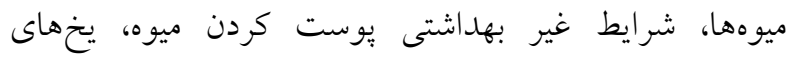
غيربهداشتى مورد استفاده در خنك كردن، نخهدارى و

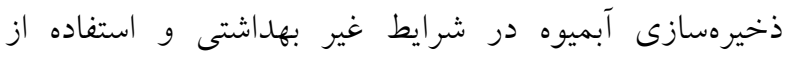

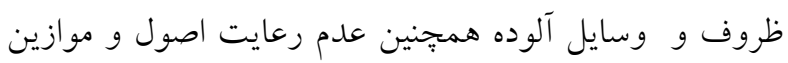

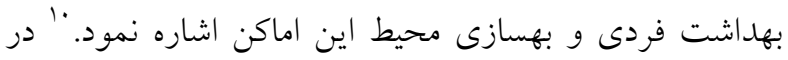
مطالعه El-Shenawy و همكاران، ميزان باكترىهاى ياتوزن در 


\section{سكينه ملايى توانى و همكاران}

در محل وجود داشت."

\section{تتيجه گيرى}

با توجه به مقايسـه بارامترهـاى كيفـى باكتريولوزيـى آب

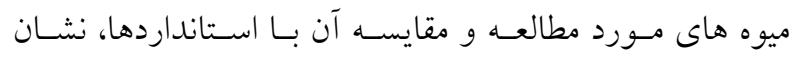
مىدهد كه همه يارامترها بالاتر از سطح استاندارد قرار داشته، و

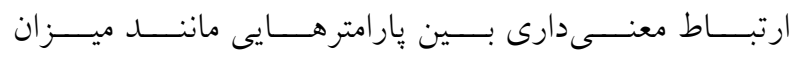
سو اد(تحصيلات) فروشند گان، ميـزان فـروش، نظافـت محـل،

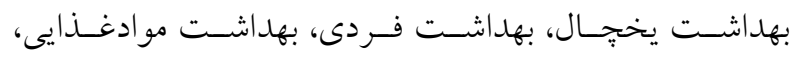
بهسازى محيط وجود داشته، كه ناشى از عدم رعايت اصول و موازين بهداشت فردى، بهداشت مواد غذايى و بهسازى محيط

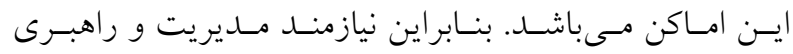
دقيقترى و تاكيد بيشترى بر رعايت آيين نامه ماده سا مىباشد.

\section{تشكر و قدردانى}

نويسند كان اين مقاله از معاونت بهداشتى دانشخاه علوم يزشكى شاهرود به جهت معاونت در جمع اطلاعات مورد نياز كمال تشكر و سياسگزارى را دارند.

\section{References}

1.Embaby E, Awni NM, Abdel-Galil MM, El-Gendy HI. Mycoflora and mycotoxin contaminated some juices. Intern J Agr Technol 2015;11(3):693-712.

2.Olorunjuwon B, Temitope B, Muibat F, Oluwadun A. Microbiological quality of some locally-produced fruit juices in Ogun State, South Western Nigeria. J Mic Res 2014;2(1):001-8.

3. Navarro-Pascual-Ahuir M, Lerma-García MJ, SimóAlfonso EF, Herrero-Martínez JM. Quality control of fruit juices by using organic acids determined by capillary zone electrophoresis with poly (vinyl alcohol)coated bubble cell capillaries. Food Chem 2015;188:596603.

4.Abdullah N, Chin NL. Application of Thermosonication Treatment in Processing and Production of High Quality

$$
\begin{aligned}
& \text { قرار كرفتن در معرض هجوم مخس خانه، مخس هاى ميـوه و } \\
& \text { كرد و غبار موجود در هوا ناشى از محيط آلوده و غيربهداشتى } \\
& \text { و همجنين علم رعايت بهداشت فردى مىتواند به عنوان منابع }
\end{aligned}
$$

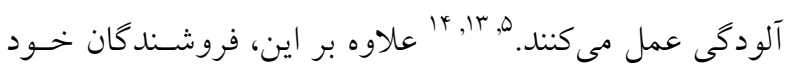

$$
\begin{aligned}
& \text { مى تواند حامل عوامل بيمارىزا مانند اشرشـياكلى، سـالمونلا، } \\
& \text { شيخالا، كمييلوباكتر و اسـتافيلوكوكوس اورئسوس و در نهايست } \\
& \text { آلوده كردن مواد غذايى شوند. شستن نامناسب و دست زدن به وسه }
\end{aligned}
$$

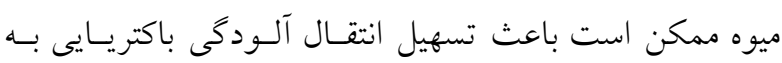

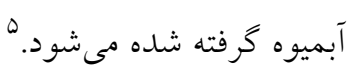

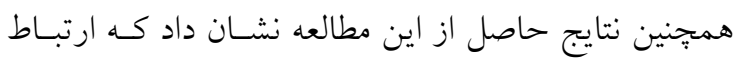

$$
\begin{aligned}
& \text { معنى دارى(جــول Y) بــين برخـى از يارامترهــا ماننــ ميـزان }
\end{aligned}
$$

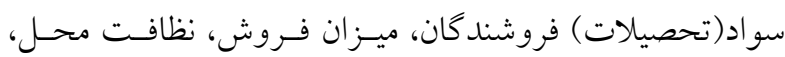

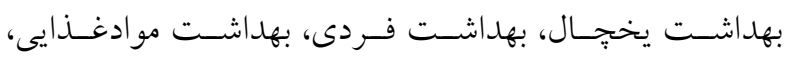

$$
\begin{aligned}
& \text { بهسازى محيط وجود دارد (P } \\
& \text { بر اساس مطالعـه انجـام شـده توسـط Reddi و همكـاران، } \\
& \text { ارتباط معنى دارى بين برخى آكاهى از ايمنـى مـواد غــذايى و } \\
& \text { شيوه هاى كه شامل شستن ظروف آبميوه گيرى يسس از آمـاده }
\end{aligned}
$$

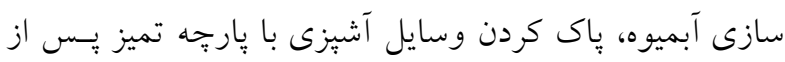

$$
\begin{aligned}
& \text { تميز كردن ظـروف، ذخيـرهسـازى ميـوه هــا بــرش در ظـرف } \\
& \text { دربسته، نظافت مكرر محل آمادهازى و نخهدارى و دفع زباله }
\end{aligned}
$$

and Safe-to-Drink Fruit Juices. Agr Sci Procedia 2014;2:320-7.

5.Simforian E, Nonga H, Ndabikunze B. Assessment of microbiological quality of raw fruit juice vended in Dar es Salaam City, Tanzania. Food Control. 2015;57:302-7.

6.Silveira AC, Aguayo E, Artés F. Shelf-life and quality attributes in fresh-cut Galia melon combined with fruit juices. LWT-Food Sci Technol 2013;50(1):343-8.

7.Naim Abadi A, Mirzaee R, Yazdani A, Rmat MR, Btalblvyy M, Yarahmadi M. Microbial study traditional ice cream and fruit juices handmade confectionary trade units And of juices Buy Bojnoord in the summer of 2008 and 2009. J North Khorasan U Med Sci 2011;2,3(2):4550. [In Persian]. 
8.Asgari E, Nourmoradi H, Delpisheh A, Karimi Z. Investigating the microbial quality of the fresh fruit juices in Ilam shopping centers. J Res Health Sys 2011;6(4):794-801. [In Persian].

9.Tavakoli HR, Farhang K, Karimi Zarchi AA, Heydari E. Bacteriological quality of ready to eat food in four military restaurants. Iran J Mil Med 2012;13(4):207-12. [In Persian].

10.Alipour V, Rezaei L, Moalemi KH, Eghbali M. Microbial Quality of Hand-Made Fresh Fruit Juice in BandarAbbas Shopping Centers, Iran. Iran J Health Environ 2011;4(1):115-24. [In Persian].

11.Reddi S, Kumar RN, Balakrishna N, Rao VS. Microbiological quality of street vended fruit juices in Hyderabad, India and their association between food safety knowledge and practices of fruit juice vendors. Int J Curr Mic App Sci 2015;4:970-82.

12. Institute of Standards and Industrial Research of Iran, 2006. Soft drinks - Fruit juice and fruit juice products Microbiological specification and test methods, Fifth edn, No. 3414, Tehran. Available from: http://www.isiri.gov.ir/ 3414.pdf [In Persian]. 13.shenawy ma, neweigy na, zaghloul ra, aly he, dairouty rk, kholy wi, et al. evaluation of the microbiological quality of street-vended juices sold in cairo. J Food Ind Nutr Sci 2013;3(1):69-80.

14.Maduka H, Onuorah O, Okpogba A, Ugwu C, Ogueche P, Dike $\mathrm{C}$, et al. Assessment of some commercial fruit juices commonly consumed in Federal University of Technology-Owerri (FUTO), by microbiological indices, 10SR-J. Pharm Biol Sci 2014;9:56-8.

15.Mangeli Zadeh NA, Khatiby Pour J, Nasseri HA, Ghasemi SM, Lotfy NA, Mshydy M, et al. Assessment of microbial contamination in the food supply in Gorgan city 2013. Iran's Mehr 2014 Environ Health Seminar. 2013.

16.Singh $\mathrm{D}$, dimri ag, chatterjee $\mathrm{r}$, pandita a, aggarwal $\mathrm{m}$. microbiological profiling of vendor and commercially packed mixed fruit juices: a case study suburb of delhi ncr, india. W J Pharm Sci 2015;4(10):1150-63.

17.Shams Khoramabadi QA, Jahanbani N. Bacteriological quality juices and ice cream in the city of Khorramabad. Coll art Six Nation Cong Envir Health 2004. 